\title{
STUDIES ON SOME FISH EGGS AND LARV $A$ OF THE MADRAS PLANKTON
}

\author{
By R. Velappan NaIR, M.Sc.* \\ (From the University Zoological Research Laboratory, Madras) \\ Received September 13, 1951 \\ (Communicated by Dr. N. Kesava Panikkar, F.A.sc.)
}

CONTENTS PAge

\begin{tabular}{|c|c|c|c|c|c|c|}
\hline 1. & INTRODUCTION & $\therefore$ & . & .. & $\cdots$ & . \\
\hline 2. & THRISSOCLES & .. & .. & .. & . & \\
\hline 3. & ANCHOVIELLA I & .. & .. & $\cdots$ & . & $\cdots$ \\
\hline 4. & ANCHOVIELLA II & . & .. & .. & .. & . \\
\hline 5. & CYNoglossus I & . & .. & .. & .. & . \\
\hline 6. & Cynoglossus II & . & . & . & . & .. \\
\hline 7. & CARANX .. & . & . & .. & .. & .. \\
\hline 8. & SAURIDA .. & .. & . & $\cdots$ & .. & .. \\
\hline 9. & A Pelagic SPawn & N Mass & . & $\cdots$ & - & . \\
\hline 10. & GENERAL REMARK & & $\ldots$ & $\cdots$ & . & - \\
\hline 11. & ACKNOWLEDGEMEN & & $\cdots$ & . & . & . \\
\hline 12. & REFERENCES & & .. & . & .. & . \\
\hline 13. & KEY TO LETTERINC & & $\ldots$ & . & .. & . \\
\hline
\end{tabular}

INTRODUCTION

THE study of fish eggs and their development, specially those of the economically important marine fishes, has received considcrable attention in recent years on account of its bearing on the understanding of the spawning season, breeding grounds and such other problems relating to the biology of fishes. It is well known that a knowledge of these aspects of the biology of food fishes is an essential pre-requisite for the proper management and exploitation of the marine fishery resources. While considerable advancc has been made in this direction in temperate countries during the last half a century, very little is known about the eggs and larvæ of tropical marine food fishes except for the work of Delsman who elucidated the early lifehistories of a numoer of fishes of the Java Sea.

- Present Address : Central Marine Fisheries Research Sub-Station, Calicut. 
$182 \cdots+2$

\section{R. VELAPPAN NAIR}

Practically very little work has been done in this direction on the food fishes of the Madras Coast. Hornell (1923) and Nayudu (1923) gave a brief account of the spawning habits, eggs and embryonic development of the flying fish, Cypsilurus. Job and Jones (1938) described the embryonic and larval development of the garfish, Tylosurus strongylurus. John (1944, Abstract) studied the eggs and developmental stages of Clupea leiogaster, Stolephorus sp., Engraulis sp. and Solea humilis. Even though this work was completed in 1936, and forms an important contribution in this field, the full paper has not so far been published.*

The present paper deals with some of the pelagic fish eggs obtained from the regular plankton collections made from the coastal waters of Madras and from the brackish waters of Cooum and Adyar within the zone of tidal influence when they were in communication with the Sea, and their subsequent development in the Laboratory. The live fish eggs from the townet ccllections were transferred to aquaria containing clean sea water and the sequence of embryonic and larval development was studied in detail. It was found that despite every precaution taken with the facilities available in the Laboratory, the larvæ did not survive the critical transition period extending from the stage at which the yolk is completely absorbed until they are able to feed independently. This difficulty has been experienced by almost all the workers in other countries as well. The early stages in the development alone are, therefore, given in this paper. The measurements of the eggs were taken in the living condition while those of the larvæ immediately after fixation.

The eggs described in this paper have been assigned to respective genera based on the broad diagnostic characters given by Delsmain of the eggs and larvæ of the different genera of fishes which have a wide distribution in the Indo-Pacific region and also taking into consideration the relative abundance of the varieties of eggs and species of fishes on different days and the gonadial condition of the common fishes. The rapid development of the eggs under tropical conditions makes it possible by such a method, especially if the eggs are in the early stages of embryonic development, to determine accurately their identity at least up to the genus. It is not until sustained work is carried out on the fish eggs in Indian waters simultaneously with a comprehensive survey of the fish fauna of the respective areas would it be possible to arrive at the specific determination of most of the eggs or to study the life-history of the numerous fishes of our Seas.

* John's paper published in the Journ.Zool.Soc. India, Vol. 3, No. 1; June 1951, when the present paper was in the course of publication. 


\section{THRISSOCLES}

Egg.-The eggs of Thrissocles occur in the Madras plankton during the months December and January. They are spherical with a diameter of $0.92 \mathrm{~mm}$. The yolk is clear and segmented without any oil globule (Fig. 1). In the earliest stage obtained, the embryo is fairly advanced in development with the myotomes distinct and the tail region free from the yolk mass.

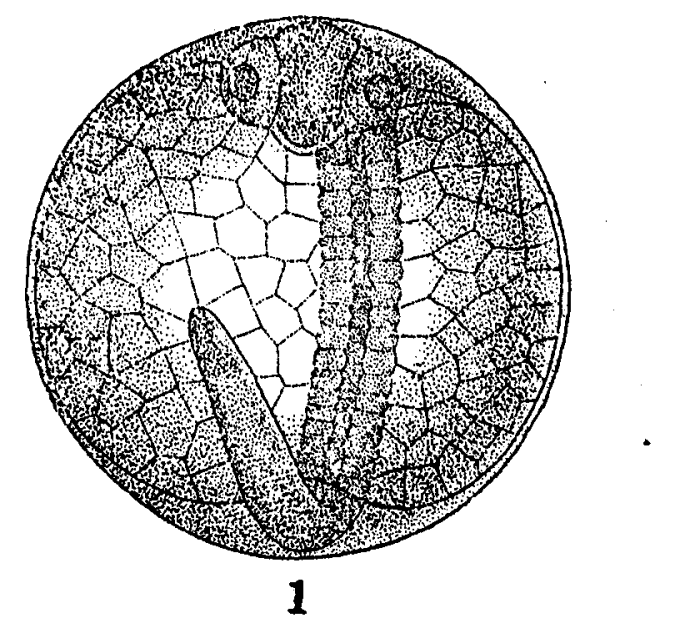

Fro. 1. Egg of Thrissocles, $\times 50$.

The eyes and the auditory vesicles are well developed. The heart has begun to function. The embryo performs occasional jerking movements inside the egg membrane.

Newly Hatched Larva.-The larvæ hatched out during the night and the next morning they were observed to rest at the bottom of the aquarium head downwards darting away when disturbed. They have also been observed to swim by the undulating movement of the body:- The larva measure $4.5 \mathrm{~mm}$. in length. The segmented yolk tapers posteriorly (Fig. 2). The rudiment of the pectoral fin is seen above the middle of the yolk. The alimentary canal is very long and the anus opens below the thirtieth myotome. Post-anal myotomes are not quite clear and as such the determination of their number in the newly hatched larvæ is difficult. The muscle fibres have the characteristic crossed arrangement of the clupeoids as observed by Delsman (1929). The fin-fold is continuous and entire.

The larvæ are perfectly transparent and are devoid of chromatophores.

One-Day Old Larva.-The one-day old larva were very active, moving about at the bottom of the aquarium in a characteristic serpentine manner. Unlike the other fish larvæ studied, there is considerable increase in size particularly in length (Fig. 3). They measure now $5.45 \mathrm{~mm}$. in length. No 
184

\section{R. VELAPPAN NAIR}

other important changes have taken place in the larvæ. The auditory vesicles and the pectoral fin rudiments have grown larger in size. There is only a slight reduction in the size of the yolk mass. The myotomes are distinct and thirty pre-anal and thirtcen post-anal myotomes could be made out. Indications of the caudal fin rays are seen in this stage.

But for the very faint brown colouration of the eyes, the larvæ remain perfectly transparent and without pigmentation.
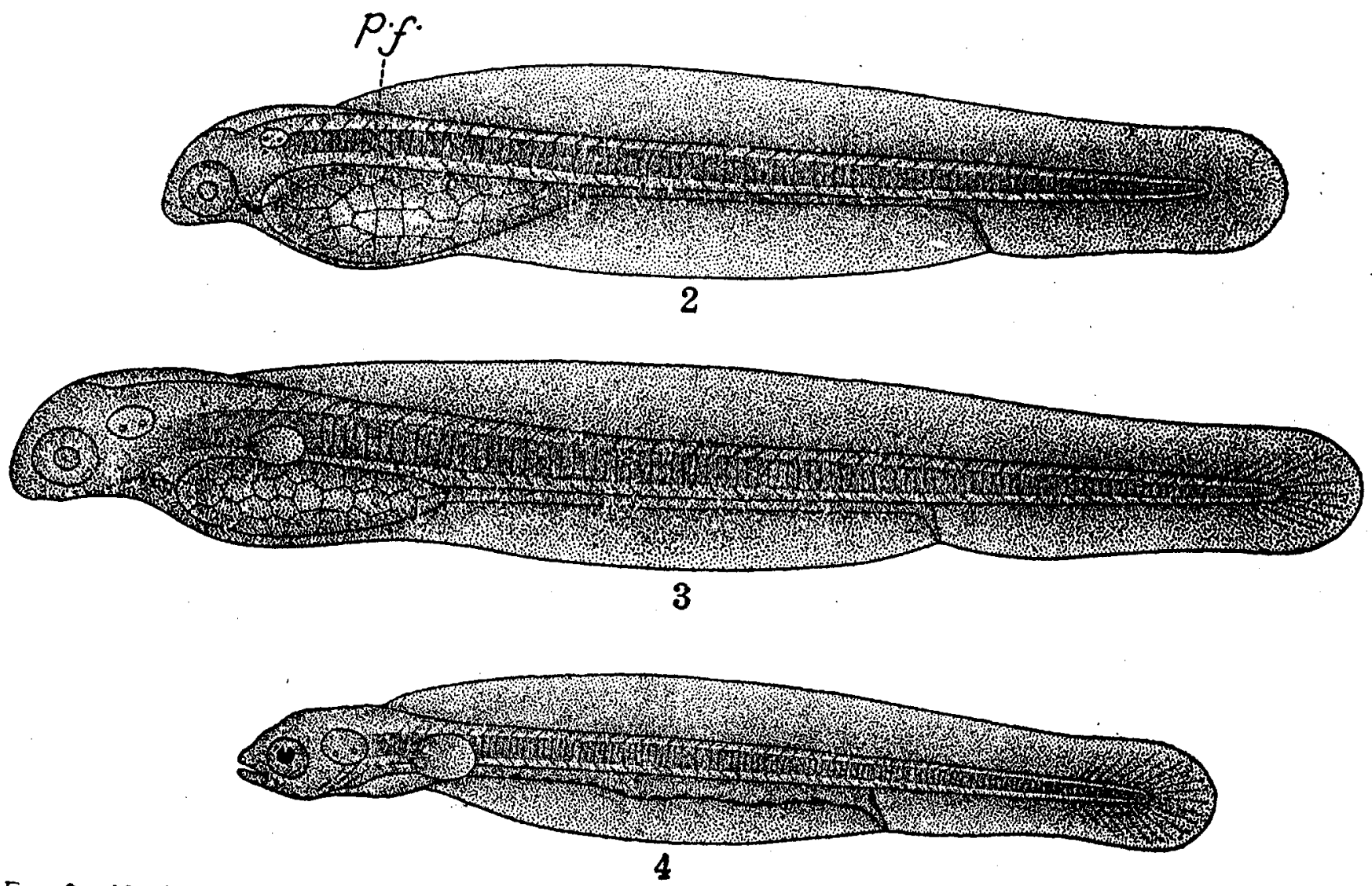
FIG. 2. Newly hatched larva of Thrissocles, $\times 30$. FIG. 3. One-day old larva of Thrissocles, $\times 30$. FIG. 4 .
Two-dily old larva of Thrissocles, $\times 20$.

Two-Day Old Larva.-The two-day old larva have been observed to sivim very activcly pecking at the sediments at the bottom of the aquarium. The larvæ measure $5.55 \mathrm{~mm}$. in length. The mouth has formed with prominent jaws (Fig. 4). The auditory vesicles are larger in size. The eyes have assumed the adult silvery colouration. The pectoral fins have also grown but no indications of the rays are seen in this stage. The yolk is almost completely absorbed. The caudal fin rays are prominent. The postericr half of the alimentary canal where the transverse folds appear
later, has enlarged. 
Studies on some Fish Eggs and Larva of the Madras Plankton 185

Black chromatophores have appeared along the entire length of the alimentary tract without any regularity in their arrangement. The larvæ remain transparent and could be easily located in the aquarium by the silvery colouration of the eyes.

Wenckebach (1887) and Nishikawa (1901) who have worked out the development of the European and the Japanese anchovies, namely, Engraulis encrasicholus and Engraulis japonicus respective and are without oil the eggs of both the species have an elongated shape the eggs of the Indian globules. Delsman (1929 and 1931) has shown thated nature of the eggs is found only in the closely related genus Anchoviella.

\section{ANCHOVIELla I}

Egg.-This type of Anchoviella eggs is very common in the Madras plankton during December and January and could be easily distinguished by its elongated shape and by the presence of a single shining oil globule in the yolk. The eggs measure $1.3 \mathrm{~mm}$. in length and $0.53 \mathrm{~mm}$. in breadth.

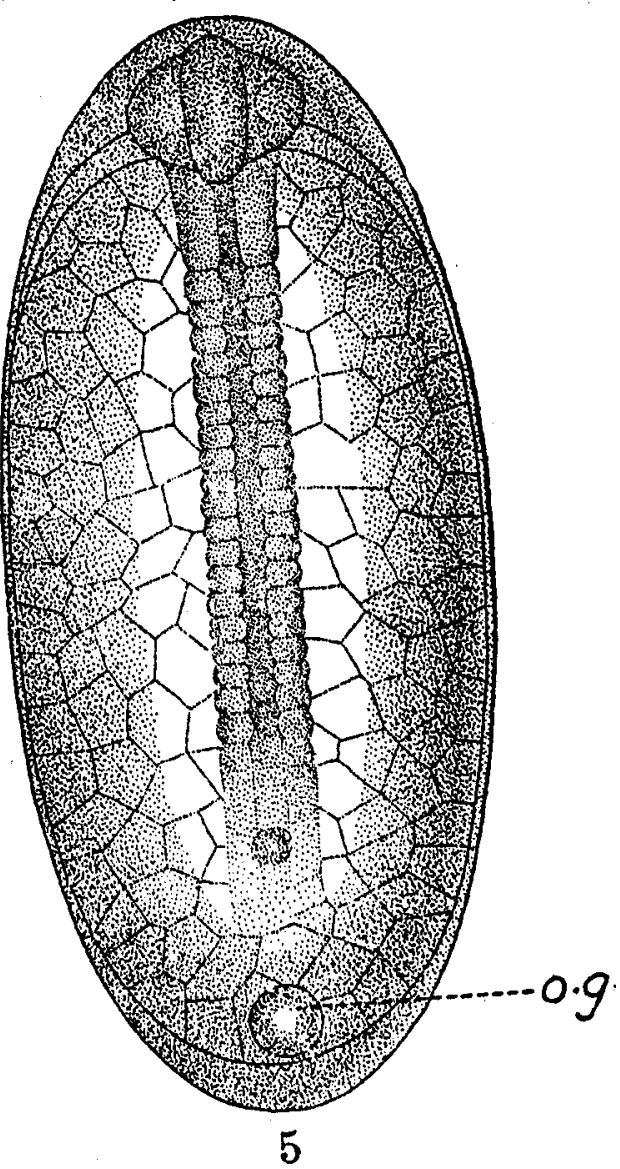

Frọ. 5. Eggg of Anchoviella $1, \times 70$. 
other important changes have taken place in the larvæ. The auditory vesicles and the pectoral fin rudiments have grown larger in size. There is only a slight reduction in the size of the yolk mass. The myotomes are distinct and thirty pre-anal and thirteen post-anal myotomes could be made out. Indications of the caudal fin rays are seen in this stage.

But for the very faint brown colouration of the eyes, the larvæ remain perfectly transparent and without pigmentation.
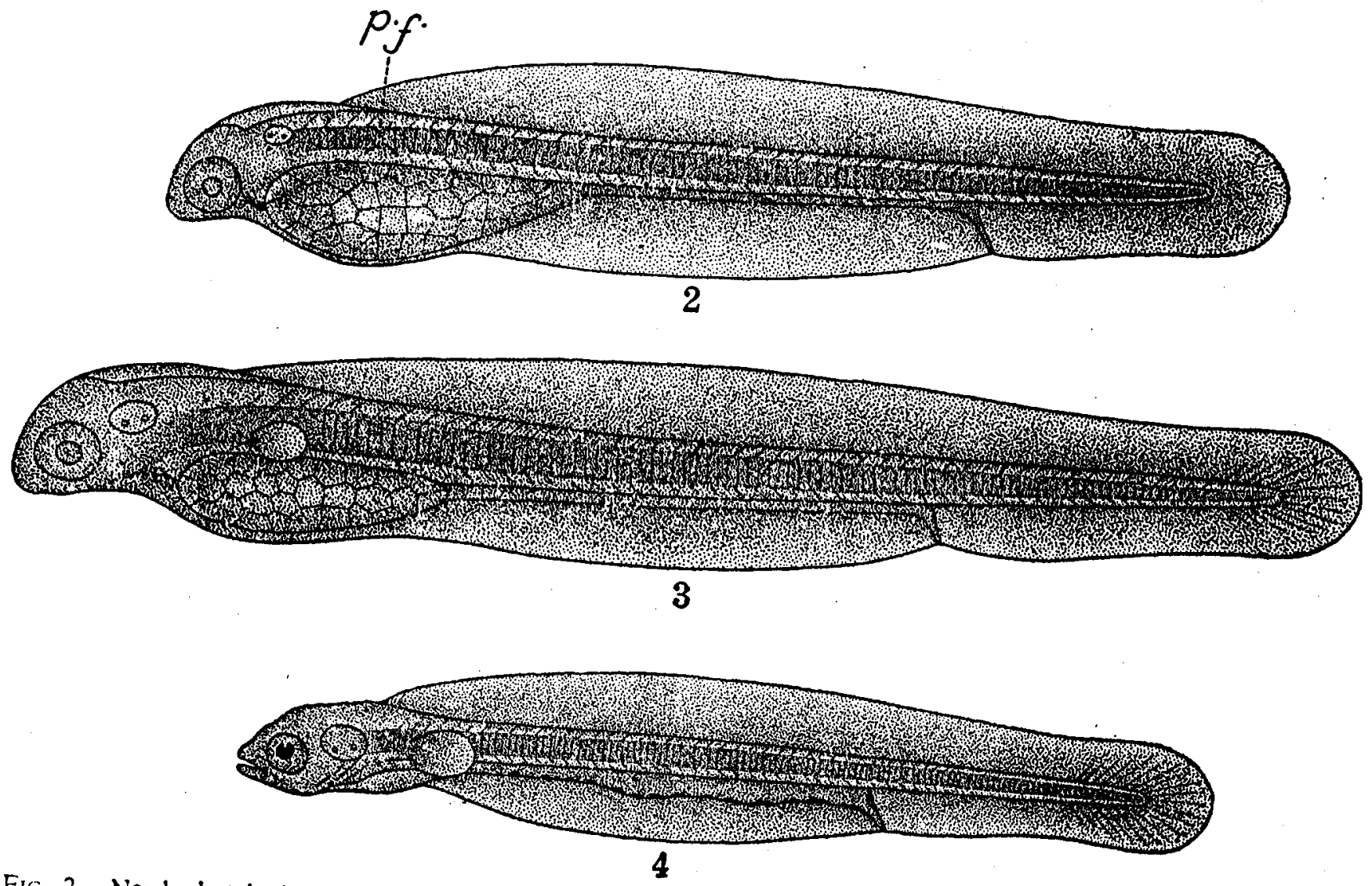

FIG. 2. Newly hatched larva of Thrissocles, $\times 30$. Fig. 3. One-day old larva of Thrissocles, $\times 30$. FIG. 4 .
wo-day old larva of Thrissocles, $\times 20$.

Two-Day Old Larva.-The two-day old larva have been observed to sivim very activcly pecking at the sediments at the bottom of the aquarium. prominent jaws (Fig. 4). The audith. The mouth has formed with have assumed the adult silvery cortory vesicles are larger in size. The eyes grown but no indications of the colouration. The pectoral fins have also almost completely absorbed. The yolk is postericr half of the aliment The caudal fin rays are prominent. The luter, has enlarged. 
Studies on some Fish Eggs and Larva of the Madras Plankton $10 \mathrm{~J}$

Black chromatophores have appeared along the entire length of the Black chromatophores have appeared along the entement. The larvæ
alimentary tract without any regularity in their arrangemente
remain transparent and could be easily located in the aquarium by the silvery colouration of the eyes.

Wenckebach (1887) and Nishikawa (1901) who have worked out the development of the European and the Japanese anchovies, namely, Engraulis encrasicholus and Engraulis japonicus respectively are without the eggs of both the species have an elongated shape and ail the eggs of both the species have an elongated she the eggs of the Indian
globules. Delsman (1929 and 1931) has shown that the elongated nature of the eggs is
species of Thrissocles arc round and that the elongiella. found only in the closely related genus Anchoviella.

ANCHOVIELLA I

Egg.-This type of Anchoviella eggs is very common in the Madras plankton during December and January and could be easily distinguished plankton during December and January and could be ea shining oil globule
by its elongated shape and by the presence of a single $1.53 \mathrm{~mm}$. in breadth.
in the yolk. The eggs measure $1.3 \mathrm{~mm}$. in length and $0.53 \mathrm{~m}$.

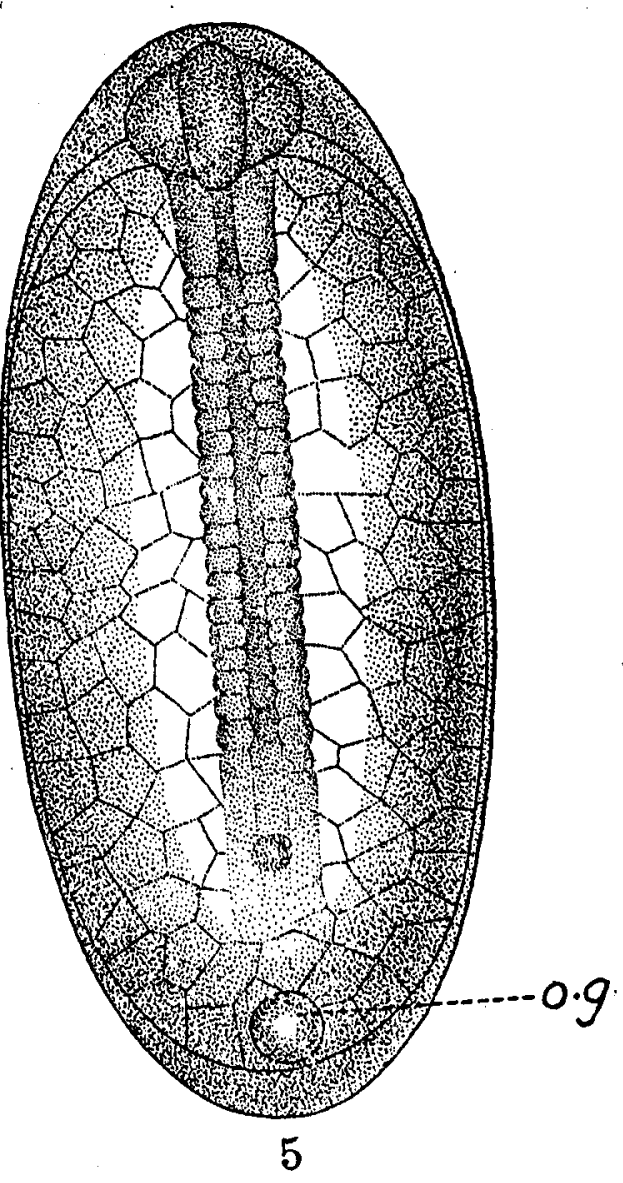

Fiọ. 5. Eggg of Anchoviella $1, \times 70$. 
The yolk is transparent and segmented with a small oil globule situated at the posterior end (Fig. 5). In the earliest stage obtained, the embryo is fairly well advanced in development, though the eyes and the auditory vesicles have not yet fully formed and the heart has not begun to function.

Newly Hatched Larva.-The larvæ had hatched out by the next morning and were observed to float at the surface of the water head downwards, moving away when disturbed. The larva which are transparent measure $3.45 \mathrm{~mm}$. in length. The oil globule is located at the posterior end of the tapering yolk mass (Fig. 6). The formation of the pectoral fin is seen above the yolk mass as a small prominence. The alimentary canal which is long opens to the exterior below the twenty-ninth myotome. The myotomes are clearly seen and about forty-three of them are present in the newly hatched larvæ. The muscle fibres show the usual crossed arrangement. The fin-fold is entire with a depression at the region of the anal opening.

The larvæ are without chromatophores.

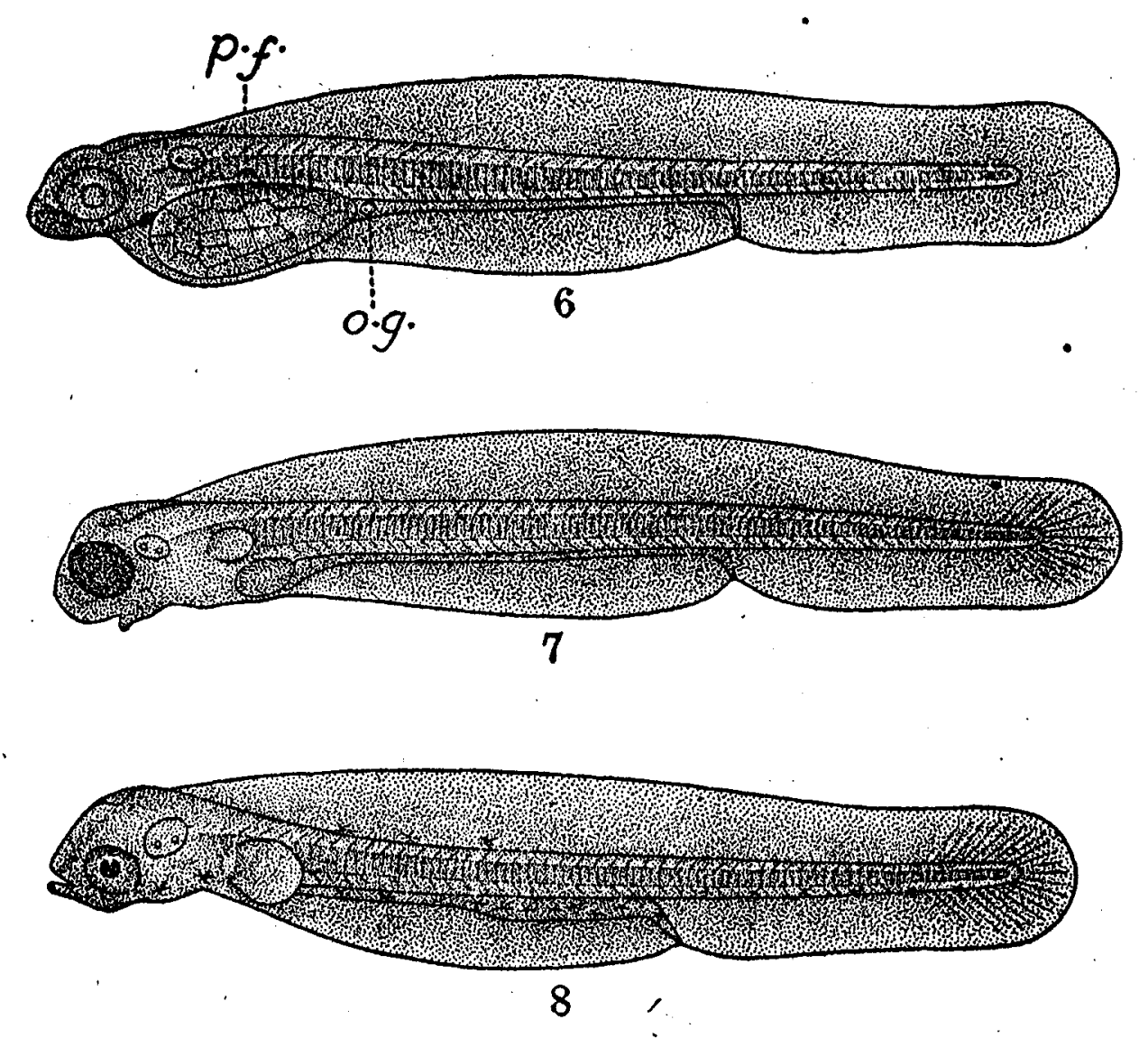

FIG. 6. Newly hatched larva of Anchoviella $I, \times 30$. Fig. 7. One-day old larva of Anchoviella I, $\times$ 30. Fig. 8. Two-day old larva of Anchoviella I, $\times 30$, 
One-Day Old Larva.-In the one-day old larvæ there is no increase in length. The yolk mass has considerably diminished in size and its segmented nature is no longer visible (Fig. 7). The oil globule has disappeared. The eyes have become pigmented and are jet black in colour with a light green sheen. The mouth has formed. The pectoral fins have grown bigger in size. The caudal fin rays are seen in this stage. There is no other change in the larvæ and they remain transparent and unpigmented except for the colouration of the eyes.

Two-Day Old Larva.-The two-day old larva are very active and could be seen swimming in the water all the time. The length has not increased but the yolk has completely disappeared and the auditory vesicles and the pectoral fins have grown larger in size (Fig. 8). The caudal fin rays are prominently seen in this stage. The posterior half of the alimentary canal has widened. The eyes have assumed the silvery colouration of the adult.

Stellate light black chromatophores have appeared in the larva and two or three such pigment cells are present in the anterior region of the base of the dorsal fin-fold. On the ventral side, these chromatophores are arranged along the alimentary canal and in a line at the base of the postanal fin-fold. One or two similar chromatophores are present on the head below, the auditory vesicles.

\section{ANCHOVIELLA II}

Egg.-A second type of Anchoviella eggs also occurs in the Madras plankton during the months December and January, along with Type I, but in lesser numbers. This type is easily distinguished from the previous one by the smaller size and by the absence of the oil globule. These eggs are also elongated in shape with a length of $1.1 \mathrm{~mm}$. and a width of $0.52 \mathrm{~mm}$. The eggs are transparent with a clear segmented yolk (Fig. 9). In all the eggs collected the embryos are well formed showing distinct myotomes with the tail portion free from the yolk mass. The eyes and the auditory vesicles are seen distinctly.

Newly Hatched Larva.-The larvæ had hatched out the next day and were seen floating in the water with the head directed downwards. The larvæ measure $3.4 \mathrm{~mm}$. in length. Here also the clear segmented yolk tapers posteriorly (Fig. 10). The rudiment of the pectoral fin is seen in the newly hatched larva. As in the previous type the alimentary canal is long and straight and the anus opens below the twenty-ninth myotome. Fortythree myotomes are present in the larvæ. The muscle fibres of the myotomes show the crossed arrangement. The fin-fold is continuous and entire, 


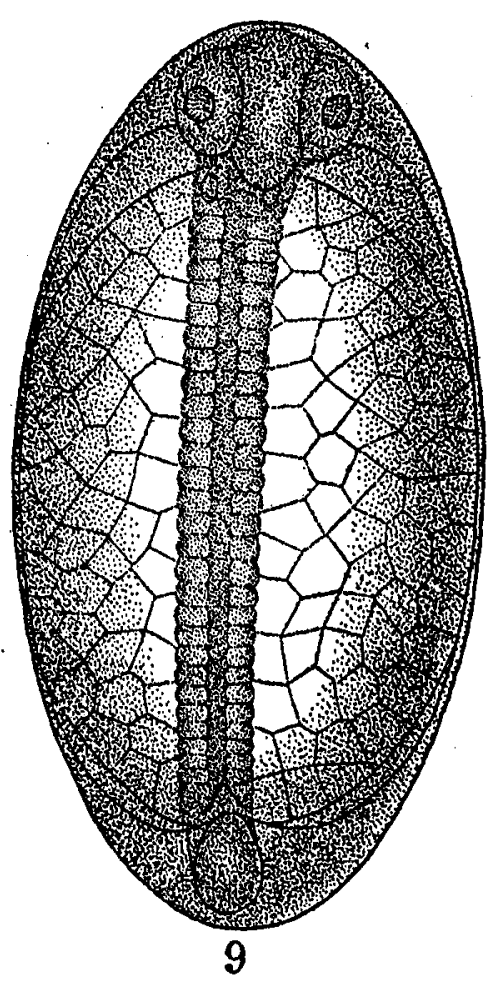

Frg. 9. Egg of Anchoviella II, $\times 70$.

The larvæ are unpigmented without any chromatophores.

One-Day Old Larva.-The one-day old larvæ have not increased in length. The yolk mass is almost completely absorbed and only a small remnant of it is seen in this stage (Fig. 11). The eyes have become jet black. The mouth has formed and the pectoral fins have increased in size. The caudal fin rays are seen faintly.

Unlike the previous type, the pigmentation has appeared even in the one-day old larvæ. This is in the form of black stellate chromatophores arranged along the alimentary tract and in a series along the ventral side
behind the anus.

Two-Day Old Larva.-In the two-day old larvæ no increase in length has been observed. The yolk is completely absorbed (Fig. 12). The mouth is prominent. The auditory vesicles have grown larger in size, so also the pectoral fins. The caudal fin rays are seen distinctly. Enlargement of the posterior half of the alimentary canal has taken place. The eyes have assumed the adult silvery colouration.

There is no appreciable difference in the pigmentation of the larva from that of the previous stage. 
Studies on some Fish Eggs and Larve of the Madras Plankton
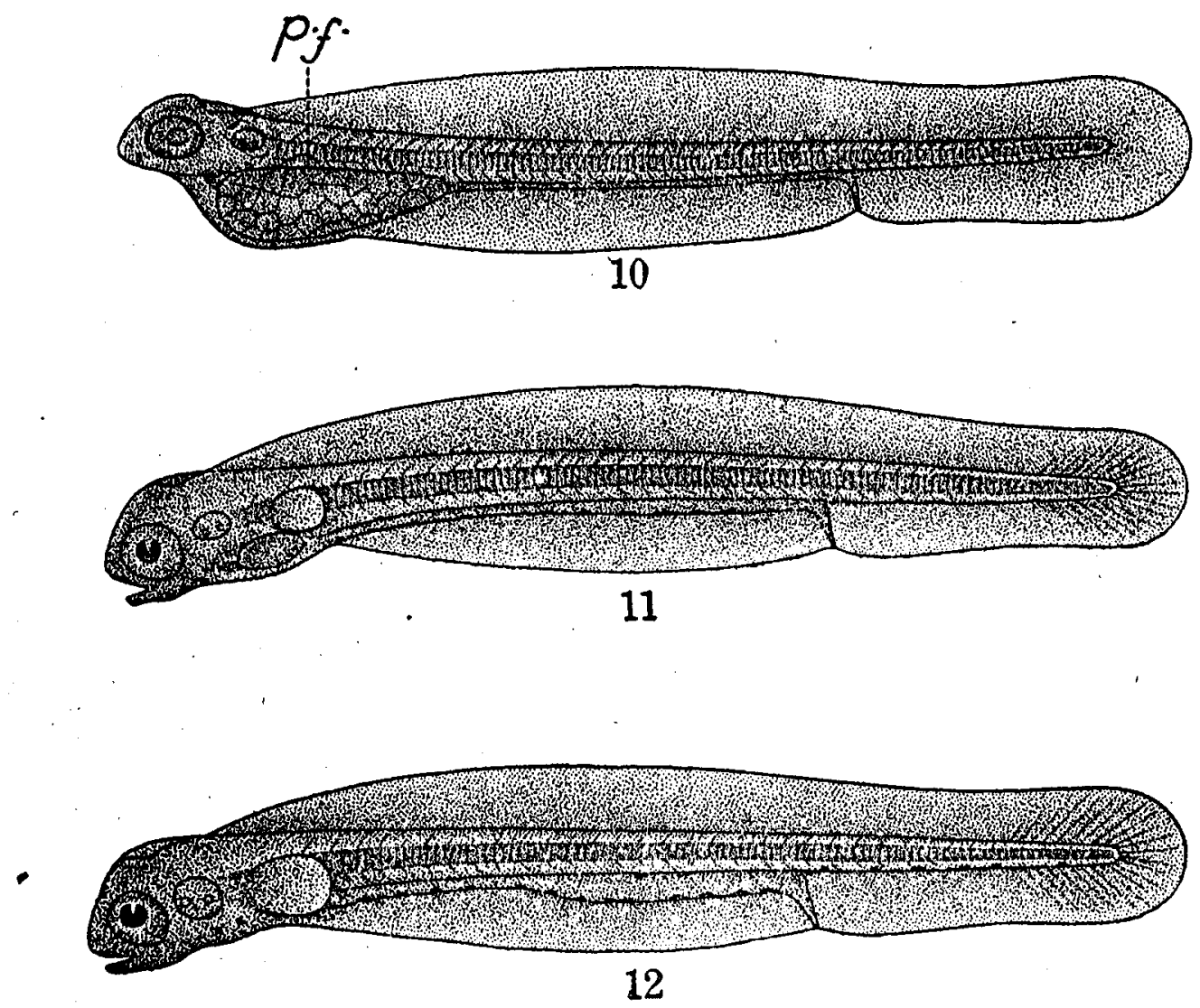

Fio. 10. Newly hatched larva of Anchoviella II, $\times 30$. FIG. 11. One-day old larva of Anchoviella II, $\times$ 30. FIG. 12. Two-day old larva of Anchoviella II, $\times 30$.

The elongated shape of the egg is seen in the European and Japanese species of Engraulis and Anchovia (Kuntz, 1913). It has been shown by Delsman (1931) that the elongated eggs found in the plankton of the Indian Seas may all prove to belong to the genus Anchoviella. Therefore, the two types of eggs dealt with in this paper have been referred to this genus. The elongated shape of the mature ovarian eggs of Anchoviella gives additional evidence in support of this assumption. Anchoviella tri is one of the commonest species of the Madras Coast (Moses, 1923) and Delsman has shown the presence of a single oil globule in the eggs of this coastal species. It is possible that Type I may belong to Anchoviella tri. Based on Delsman's conclusions, it may be stated that Type II belongs to a species of Anchoviella found in the open Sea rather than along the Coast.

\section{Cynoglossus I}

Egg.-This type of Cynoglossus eggs is very common in the Madras plankton during December and January. The eggs are spherical with a diameter of $0.6 \mathrm{~mm}$. A number of oil globules are present in the clear and 
unsegmented yolk (Fig. 13). They are of different sizes and their number varies from sixteen to thirty. In all the eggs collected, the embryos are well developed showing the myotomes, the eyes, the auditory vesicles and the Kupffer's vesicle distinctly. The heart is also functional.

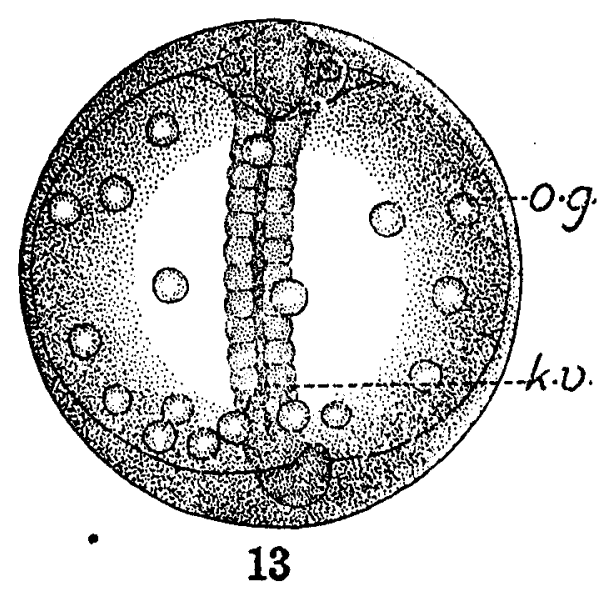

Fig. 13. Egg of Cynoglossus I, $\times 70$.

Newly Hatched Larva.-The next morning the newly hatched larvæ were observed to rest at the bottom of the aquarium, the slightest disturbance making them dart from place to place. They measure $2.35 \mathrm{~mm}$. in length. The oil globules are crowded near the basal portion of the yolk (Fig. 14). The myotomes are distinct and about fifty-five are present in the larvæ. The short alimentary canal opens to the exterior below the twelfth myotome. The fin-fold is continuous and entire with a depression at the region of the anus.

The larval pigmentation is conspicuous and is confined to certain definite regions. Yellow branching chromatophores are present on the eyes and on the dorsal surface of the yolk mass. On the body similar chromatophores are concentrated in five groups. The first group is on a level with the centre of the yolk mass, the second above the anal opening and the remaining ones are equidistantly arranged along the post-anal portion, of the body. The last group of chromatophores is the largest in size. The fin-fold is free from chromatophores.

One-Day Old Larva.-The next day, the larvæ have grown in size and measure $3 \mathrm{~mm}$. in length. The yolk has dwindled in size and the fate of the oil globules could not be observed owing to the intense covering of the yolk mass by yellow chromatophores (Fig. 15). The pectoral fin has developed above the yolk mass and is small in size. Caudal fin rays have formed. No other important changes are sęen in the larvæ. 
Pigmentation in the one-day old larva is more pronounced because of the intensification and ramification of the yellow chromatophores, particularly in the last three groups of pigment cells. The inner side of the eye is also densely pigmented. The yolk mass is completely covered with yellow chromatophores amidst which are found black stellate chromatophores. Similar black chromatophores are present arranged in a line along the ventral side of the middle third of the body, the chromatophores being placed equidistant from one another.

Two-Day Old Larva.-The two-day old larvæ are very active and there is no increase in length. The yolk mass has become very small (Fig. 16). The auditory vesicles have grown larger in size. The mouth has formed. In this stage, the characteristic coil of the alimentary canal has taken shape behind the yolk mass and the vent is situated below the eighth myotome. At the origin of the dorsal fin-fold a tentacle is in the course of formation with about three faint rays in it. The pectoral fins have become larger in size. The caudal fin rays are seen prominently in this stage.

There is very little change in the pigmentation. A few black chromatophores have appeared anterior to the eyes and on the ventral side of the head. The tentacle is pigmented deeply with yellow chromatophores amidst which are present a few black stellate chromatophores. The eyes are completely covered with yellow chromatophores. There is a tendency for the chromatcphores of the groups on the body to disappear, particularly in the middle ones.

Three-Day Old Larva.-In the three-day old larvæ, very few changes have taken place. The larvæ are of the same length. The yolk mass has almost disappeared (Fig. 17). A few oil globules have been noticed to persist in this stage. They are rendered visible by the atmost complete disappearance of the dense encrusting pigment cells. The tentacle has beccme prominent in this stage. The pectoral fins have grown to their full size but the rays are not yet differentiated. The eyes have assumed the adult silvery appearance.

The prominent yellow colouration has faded considerably, this fading being more pronounced in the anterior region where only a few chromatophores still remain over the yolk mass and on the dorsal side of the posterior extremity of the alimentary canal. Even the two posterior pigment groups persisting in the three-day old larvæ have begun to show signs of disintegration.

Four-Day Old Larva.-No appreciable change has been observed in the four-day old larva. There is no increase in length. The yolk mas 


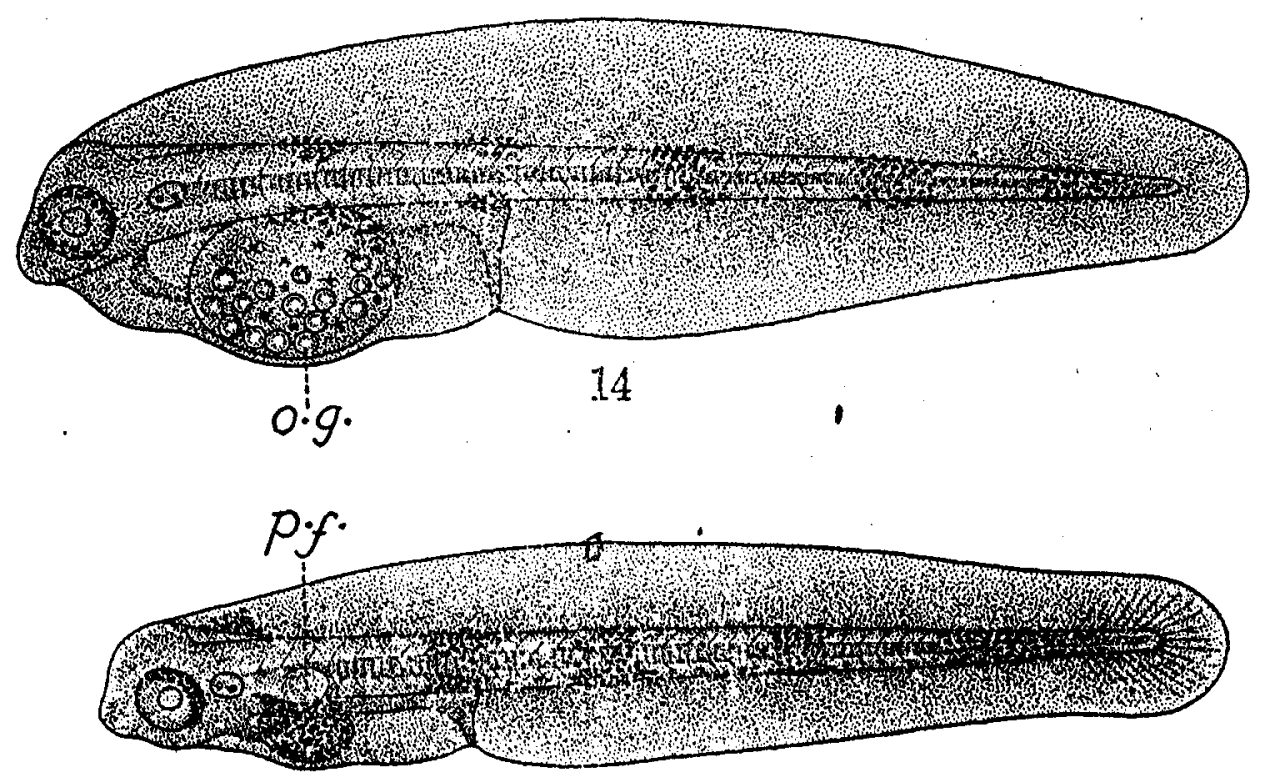

15

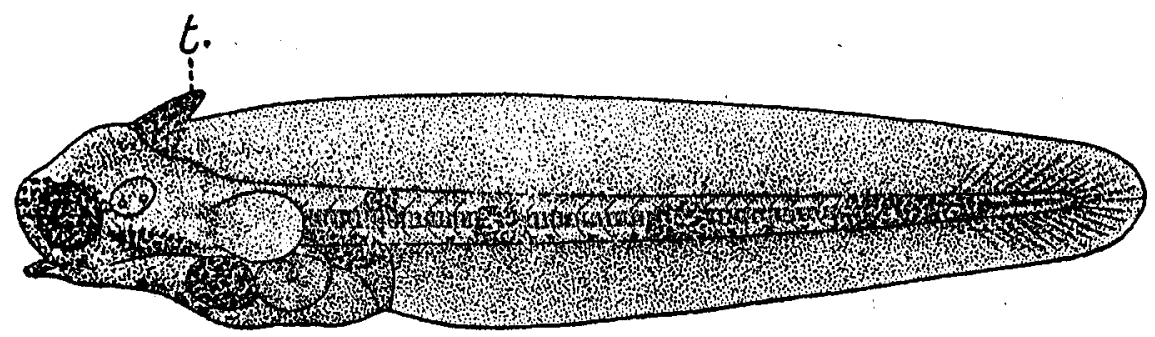

16

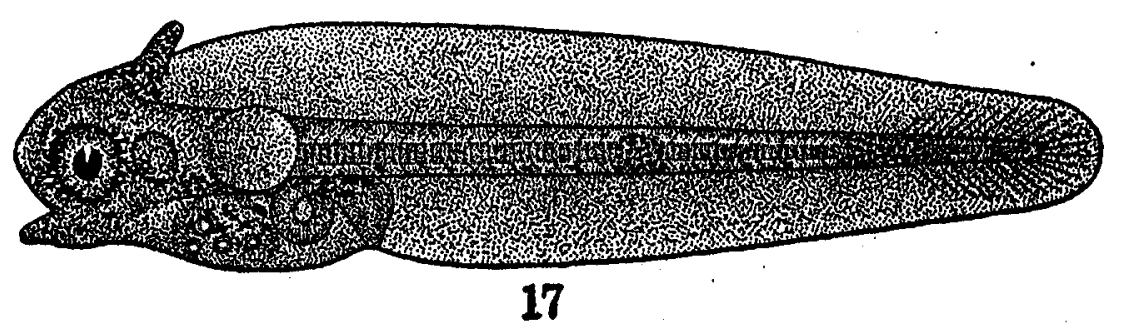

Fig. 14. Newly hatched larva of Cynoglossus I, $\times$ 45. Fig. 15. One-day old larva of Cynoglossus I, $\times 30$. Fig. 15. Two-day old larva of Cynoglossus I, $\times 30$. Fig. 17. Three-day old larva of Cynoglossus I, $\times 30$.

and the oil globules have completely disappeared. The tentacle has grown considerably longer and is very prominent in this stage (Fig. 18). Three to four rays are seen extending throughout its length.

The pigmentation has almost disappeared in some of the specimens where only the posterior group of chromatophores and a few scattered 


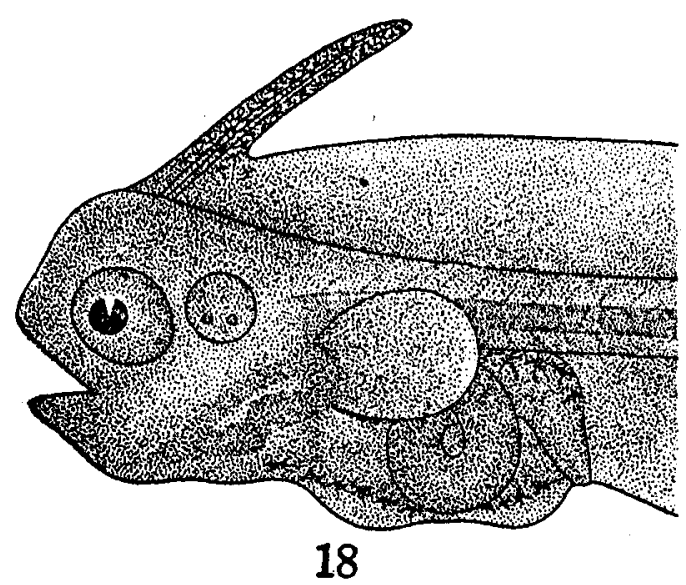

Frg. 18. Head region of the four-day old larva of Cynoglossus I, $\times 45$.

chromatophores along the alimentary canal are present. The pigment?tion of the tentacle remains unchanged and it forms a conspicuous part of the larvæ.

\section{Cynoglossus II}

Egg.-This type of Cynoglossus egg is very rare in the Madras plankton and occurs during the months December and January. These eggs are large and spherical with a diameter of $0.83 \mathrm{~mm}$. The yolk is clear and ur.segmented with a large number of differently sized golden yellow oil globules varying in number from forty to fifty (Fig. 19). In the few eggs collected,

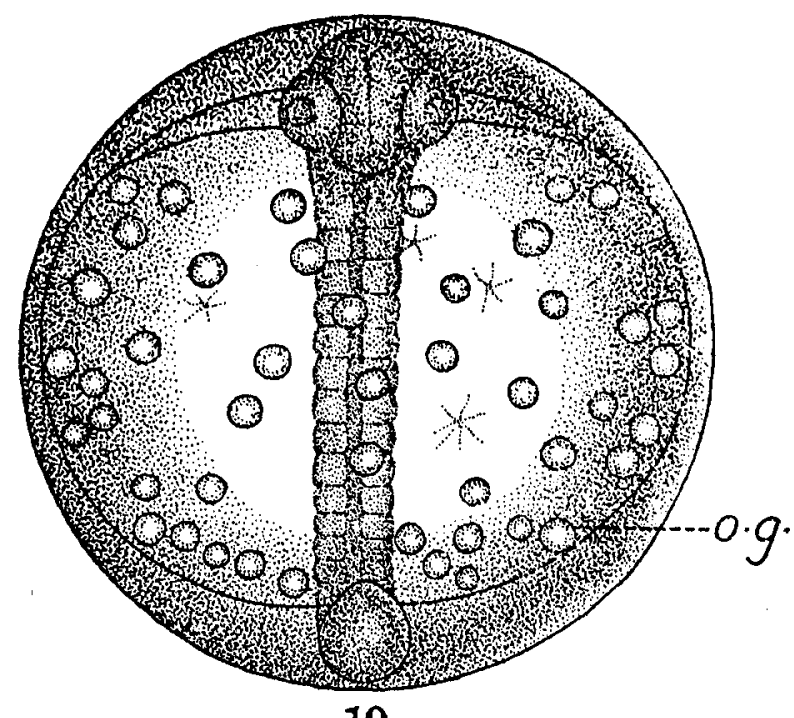

19

FIG. 19. Egg of Cynoglossus II, $\times 70$.

the embryo is in an advanced stage of development with the eyes and the auditory vesicles prominent and the heart functioning. 
Newly Hatched Larva.-The larvæ had hatched out by the next morning and were quite inactive resting at the bottom of the aquarium. The larva measure $2.8 \mathrm{~mm}$. in length. The yolk mass is elongated in shape with the oil globules arranged in the basal region (Fig. 20). The auditory vesicles are small. The alimentary canal is short and the anus opens below the thirteenth myotome. The myotomes are very clear and about thirty-two of them are present in the newly hatched larvæ. The fin-fold is continuous and entire.

The pigmentation is feeble and the chromatophores are spread more or less uniformly over the surface of the larvæ. The border of the fin-fold contains numerous highly branched brown chromatophores distributed uniformly. Black stellate chromatophores are present on the body and on the yolk mass without any regularity in their disposition.

One-Day Old Larva.-The one-day old larvæ have grown slightly longer and measure $2.95 \mathrm{~mm}$. in length and have been observed still resting at the bottom of the aquarium moving away only when disturbed. The yolk mass is reduced considerably as a result of which the posterior portion of the alimentary tract is prominent in this stage (Fig. 21). There is no indication of the formation of the mouth. The pectoral fin rudiment has appeared above the yolk.
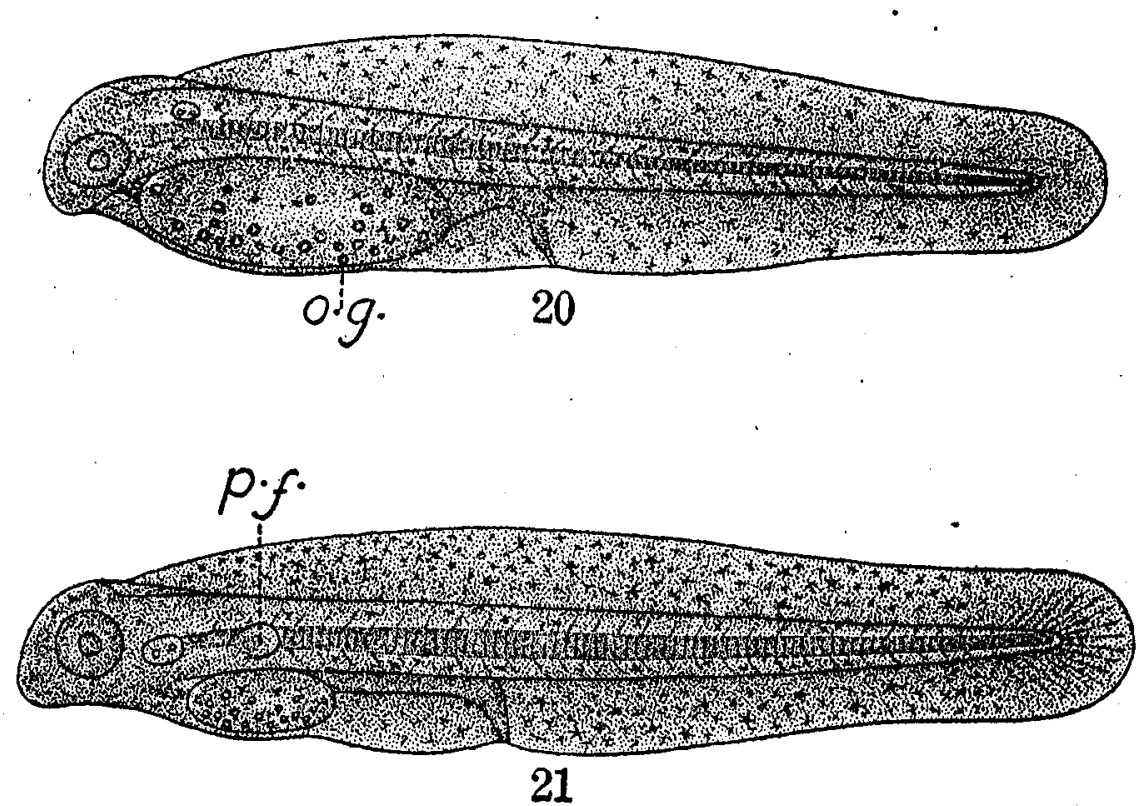
Fig. 20. Newly hatched larva of Cynoglossus II, $\times 30$. Fro. 21. One-day old
larva of Cynoglossus II, $\times 30$.

There is a slight intensification of the brown chromatophores particularly along the margin of the fin-fold. Highly branching brownish black 
chromatophores have appeared on the fin-fold in small numbers. The caudal region of the larvæ is almost free from chromatophores.

The subsequent stages have not been obtained owing to the rarity of the eggs in the plankton collections.

Originally the two types of eggs described above were doubtfully referred to the genus Solea, since this was the only known genus the eggs of which possess a large number of oil globules (Ehrenbaum, 1909). Subsequent studies on the eggs, larval development and metamorphosis of the flat-fishes of the West Coast where they contribute to an important fishery, have shown that the eggs of Cynoglossus also possess numerous oil globules in the unsegmented yolk. These investigations have also brought to light that the tentacle is not developed in the larva of Solea while it forms a characteristic larval feature of Cynoglossus. These findings clearly show that the eggs belong to Cynoglossus, a common flat-fish of the Indian waters.

\section{CARANX}

Egg.-The eggs of Caranx are very common in the Madras plankton during December and January. The eggs are perfectly spherical with a diameter of $0.68 \mathrm{~mm}$. The unpigmented yolk is segmented showing large vacuoles (Fig. 22). There is a single large oil globule covered by yellow

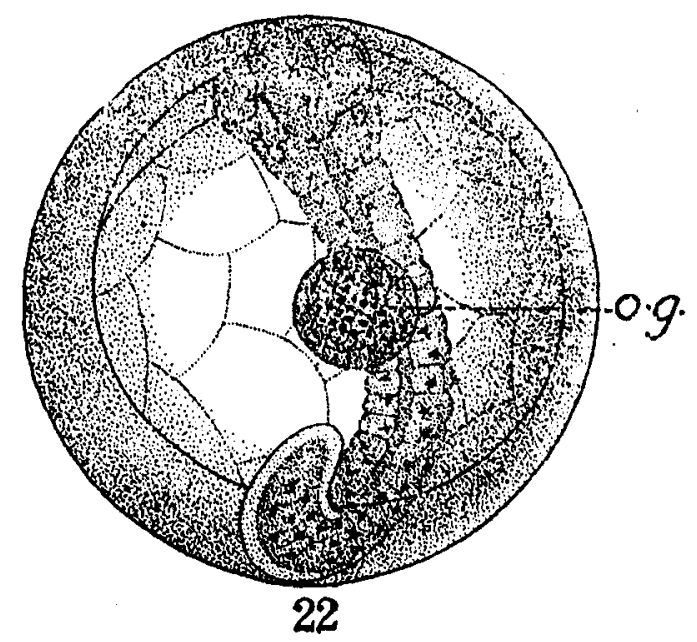

FIG. 22. Egg of Caranx, $\times 70$.

ramifying chromatophores. Deep black pigment cells are concentrated at the base of the oil globule. The embryo in the eggs collected is well developed with the tail region free from the yolk. Twitching movements are performed by the tail of the embryo. The eyes and the auditory vesicles are distinct as also a functional heart. 
The embryo is pigmented with yellow chromatophores. On the head the stellate pigment cells are few in number. The chromatophores of the body and the tail region do not branch conspicuously and the pigmentation is slightly more intense in the latter region.

Newly Hatched Larva.-The next morning the larvæ had hatched out of the eggs and were observed to rest at the bottom of the aquarium with the head downwards. The larvæ measure $2.5 \mathrm{~mm}$. in length. The segmentation of the yolk mass is not visible in the newly hatched larva (Fig. 23). The oil globule is situated at the posterior end of the yolk mass. There is no indication of the formation of the mouth or the pectoral fins. The atimentary canal is short and opens to the exterior below the fifteenth myctome. The myotomes are clear and about thirty-four are present in this stage. The fin-fold is continuous and entire with a depression at the region of the anal opening.

The larvæ are prominently pigmented. The inner side of the eye is covered with highly branched yellow chromatophores. Similar chromatophores are present on the body arranged in six groups of which the fourth is the most prominent. The oil globule is also covered completely with the same type of pigment cells. A few black chromatophores are found scattered along the body.

One-Day Old Larva.-The one-day old larvæ show very little increase in length as they measure only $2.7 \mathrm{~mm}$. The yolk mass has diminished in size considerably. The oil globule persists, but is smaller in size (Fig. 24). The pectoral fin has formed but there is no indication of the formation of the mouth. The caudal fin rays are seen faintly. No other important changes are seen in this stage and the pigmentation also remains unchanged.

Two-Day Old Larva.-In the two-day old larvæ there is no increase in length. The yolk has completely disappeared and its position is indicated by the few chromatophores which were present on the yolk mass (Fig. 25). The auditory vesicles and the pectoral fins have grown larger in size. The mouth has formed. The caudal fin rays are prominently seen in this stage. The eyes have become black in colour. There is a tendency for the general pigmentation to fade in the two-day old larvæ.

The segmented nature of the yolk and the black and brown pigmentation of the oil globule ant the embryo are characteristic features of carangoid eggs (Delsman, 1926). The egg described here has, therefore, been referred to the genus Caranx. Further support is given by the fact that the eggs have been noted to occur in the plankton on days when these fishes are common in the fishermen's catches. 

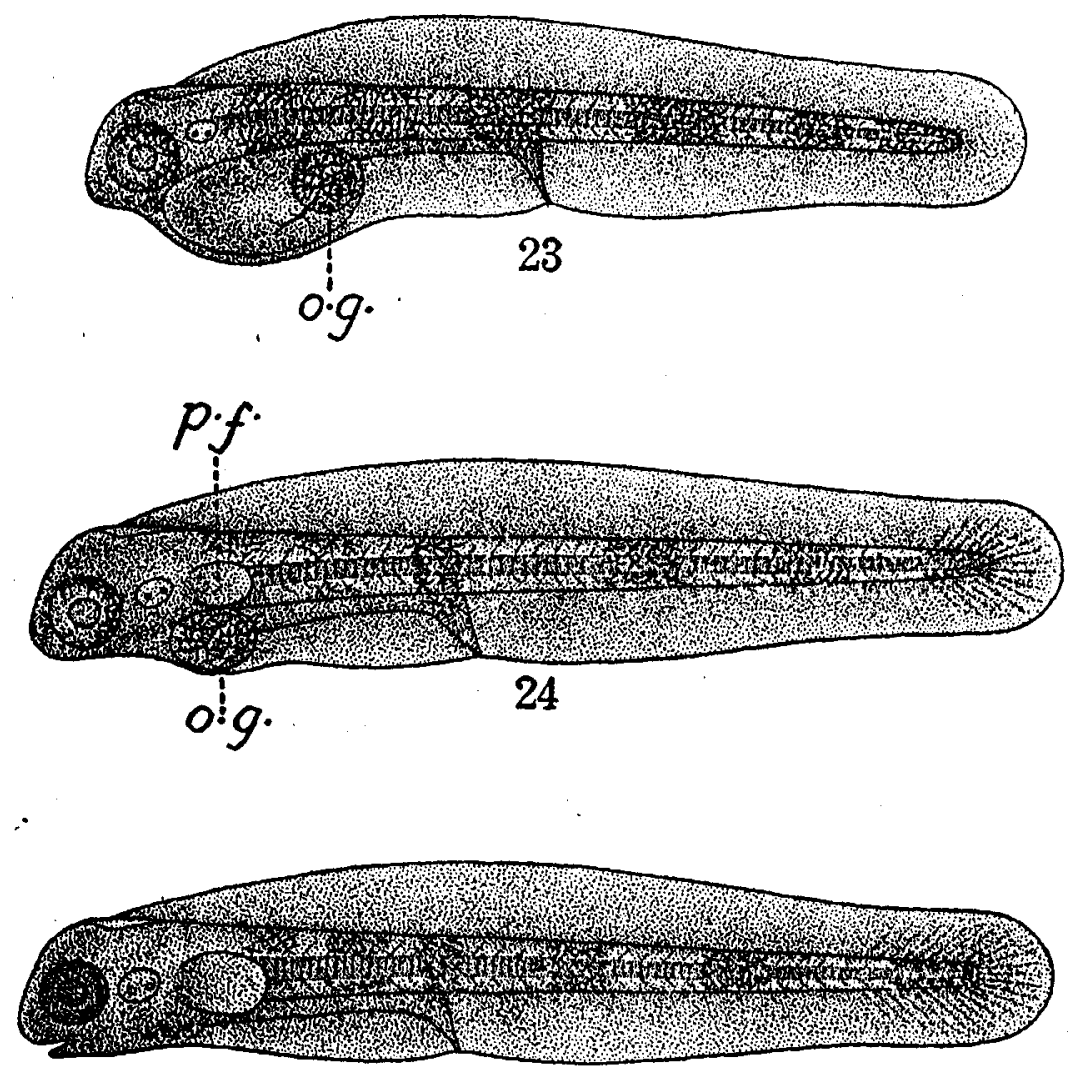

25

FIG. 23. Newly hatched larva of Caranx, $\times$ 30. FIG. 24. Onc-day old larva of Caranx, $\times$ 30. FIG. 25. Two-day old larva of Caranx, $\times 30$.

\section{SAURIDA}

The eggs of Saurida are very rare in the Madras plankton occurring only in some of the collections made during the months December and January and less frequently in the collections of September. These eggs are easily distinguished from the other planktonic eggs by the presence of a network of fine hexagonal meshes on the outer surface of the egg membranc (Fig. 26). The hexagonal meshes project in the form of ridges which are easily seen when viewed from the side (Fig. 27). The eggs are perfectly spherical with a diameter of $1.02 \mathrm{~mm}$. They are transparent without any pigment or oil globule. The yolk is clear and unsegmented and fills practically the entire space inside the egg membrane (Fig. 28). The embryo in the eggs collected is in the very early stage of development indicating that they were probably liberated during the early hours of the morning. Unlike the other pelagic fish eggs, the development of the eggs of Saurida is very slow. The network of ridges on the egg membrane affords additional protection to the egg which is necessitated by the longer time taken for the development of the embryo. 


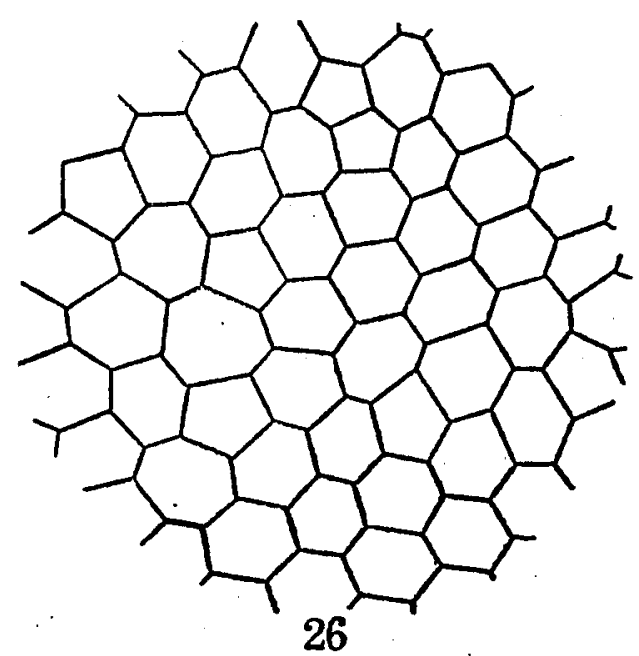

FIG. 26. Portion of the sculpturing on the surface of the egg of Saurida, $\times 180$.

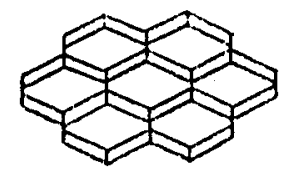

27

Fig. 27. Portion of the sculpturing on the surface of the egg of Saurida, Side view, $\times 180$.

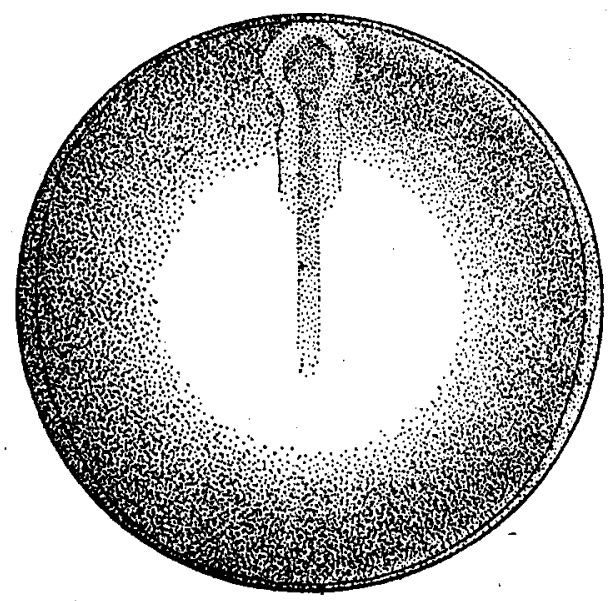

28

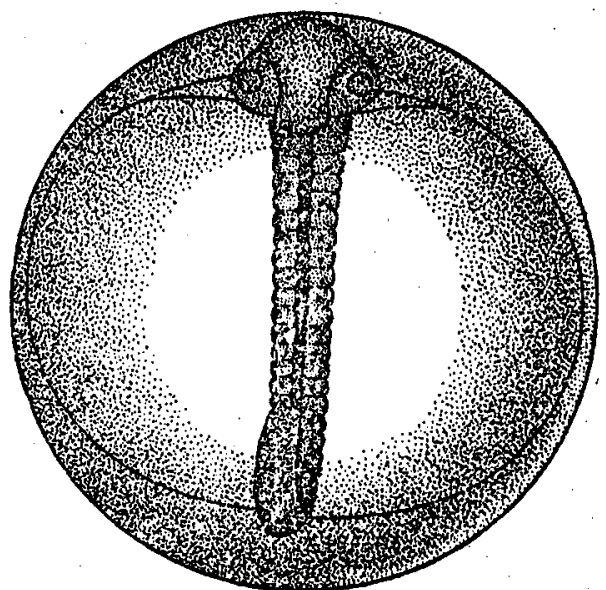

29

Fig. 28. Egg of Saurida, $\times 50$. FIG. 29. Egg of Saurida, Second day, $\times 50$.

Second Day.-The embryo is fairly large and occupies nearly twothirds the circumference of the yolk mass (Fig. 29). The eyes and the auditory vesicles have formed. The heart has begun to beat very slowly. The myotomes are clearly differentiated. A few black unbranched chromatophores scattered over the embryo have appeared. The yolk mass has 
diminished in size and wide spaces have formed in the anterior and posterior regions. Very slow movements are performed by the embryo in this stagc.

Third Day.-The embryo has grown larger in size and encircles the yolk mass completely (Fig. 30). The pectoral fins have formed as rounded buds in the anterior region. There is an increase in the number of chromatophores. The yolk mass has become smaller than in the previous stage. The heart pulsates rapidly, and the larva performs occasional movements inside
the egg membrane.

Fourth Day.-The embryo has almost completed the full growth and lics curled up inside the egg membrane (Fig. 31). The pectoral fins have grown

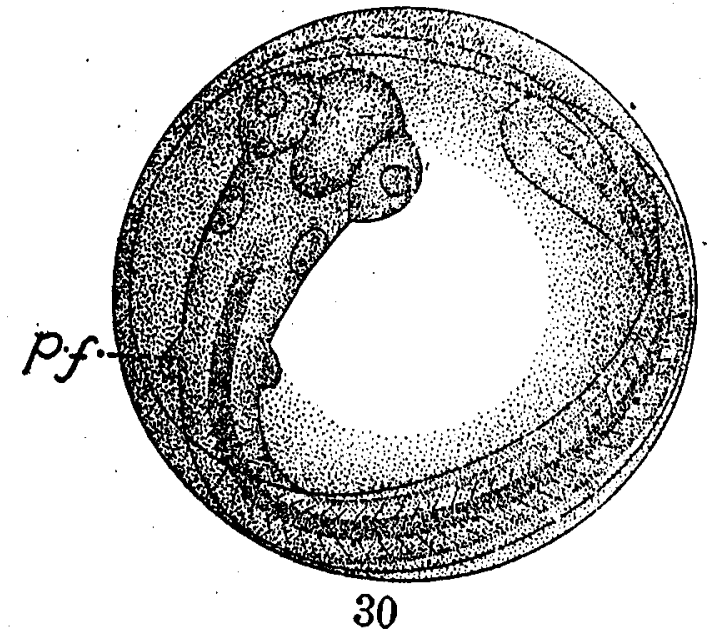

FIG. 30. Egg of Saurida, Third day, $\times 50$. Fig 31

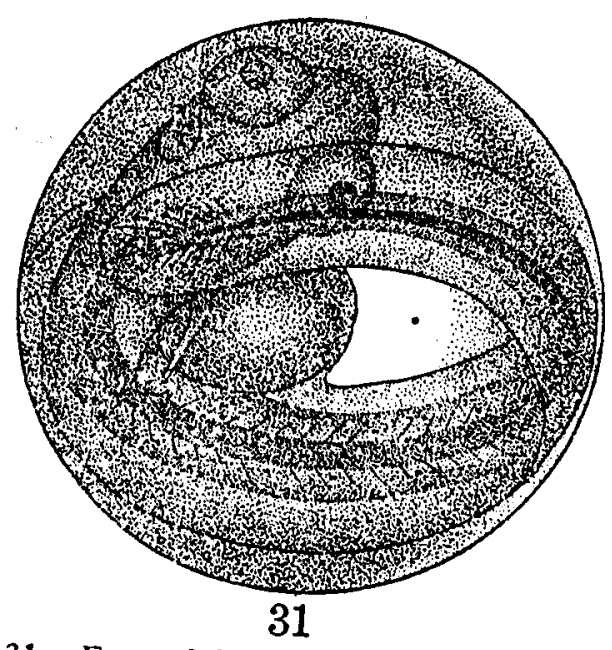

Egg of Saurida, Fourth day, $\times$ so. rays are present and appearance. Faint indications of the caudal fin the caudal region. There is a concentration of black chromatophores in embryo is very active and mass is reduced considerably in size. The brane changing its position frequently.

The next morning the larva were seen to have escaped from the egs membranes but were lying in a dead and decomposing condition very probably because of the attacks of ciliates which had made a convenient shelter of the hexagonal meshes of the egg membrane.

Pelagic eggs with hexagonal meshes on the surface of the egg membrane are not rare; species of Callionymus, Synodus, etc., are known to have such and (or) Saurida. At the same time he has pointed out that Saurida 
tumbil is the commonest of all the species of lizard-fishes in the Java Sea. Since the two types of eggs which he has described are equally common, he could not decide which of the two types of eggs belongs to Saurida tumbil.

In the Madras Coast Saurida tumbil is very common and Moses (1923) mentions only this fish under the Family as common during January and February during the north-east monsoon and in August and September during the south-west monsoon. Only one type of hexagonally sculptured eggs has been observed in the Madras plankton and as such this egg could be assigned to Saurida tumbil. Support is given for this assumption by the similarity between the eggs of the Madras plankton and Egg A described by Delsman from the Java Sea particularly in the size of the egg and the pigmentation of the embryo. Further, the time of occurrence of the eggs in the Madras plankton is also identical with that of the adults in the fishermen's catches along the Madras Coast.

\section{A Pelagic Spawn Mass}

The occurrence of pelagic spawn masses of marine fishes in the Madras plankton is an unusual phenomenon and to my knowledge no such spawn mass has been so far collected from this Coast during the last ten years. A large spawn mass, having a general resemblance to a molluscan spawn mass, was collected in the townet on the 21st September 1945. The spawn mass is perfectly transparent, ribbon-shaped and measures about a metre in length, $15 \mathrm{~cm}$. in width and $15 \mathrm{~mm}$. in height (Photograph 1). The entire outer surface of the spawn mass is finely sculptured with a hexagonal network which has a shining appearance (Fig. 32). Numerous capsules are

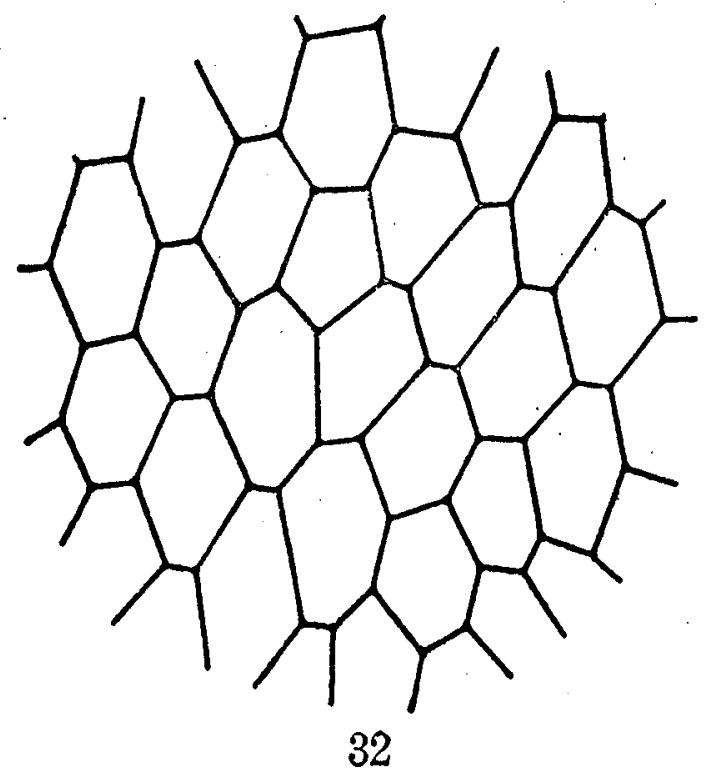

Fig. 32. Portion of the sculpturing on the surface of the spawn mass, $\times 300$. 
present inside the jelly-like material of the spawn mass. The capsules also have a hexagonal shape and are arranged in a single layer only. Each capsule encloses two to four and rarely five eggs (Fig. 33). The cggs are

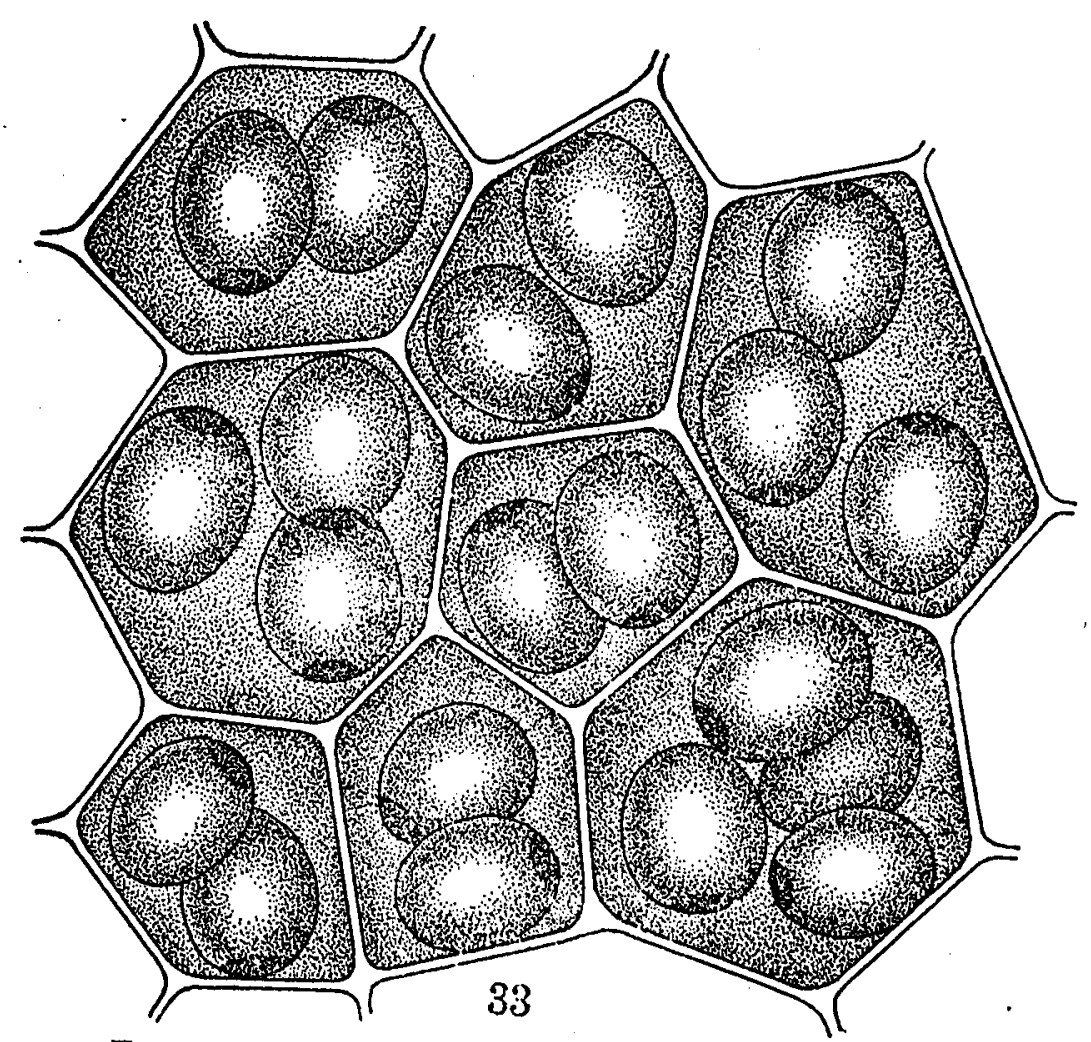

Fro. 33. A portion of the spawn mass, $\times 24$.

oval in shape measuring $0.62 \mathrm{~mm}$. in length and $0.52 \mathrm{~mm}$. in width (Fig. 34). The yolk is very clear, transparent and unsegmented in this stage. The blastoderm occupies one end of the oval yolk mass and is slightly opaque. The yolk mass touches the egg membrane on the sides, but a little space is present at the anterior and posterior ends. Judging from the stage of development of the blastoderm, the spawn mass must have been laid on the night of 20th September 1945. The spawn mass was reared in the aquarium to study the subsequent developmental stages.

Second Day.-The eggs have assumed a perfectly spherical shape with the embryos in a well advanced stage of development and occupying nearly half the circumference of the yolk mass (Fig. 35 and Photomicrograph 2). The eyes have formed. The myotomes are distinct and ten are clearly seen in this stage. A fairly large Kupffer's vesicle is present on the ventral side of the embryo at the posterior end. The larva and the yolk mass are transparent without any pigmentation. The yolk in this stage is segmented clearly and the pattern of vacuolation reminds one of the clupeoid eggs, 


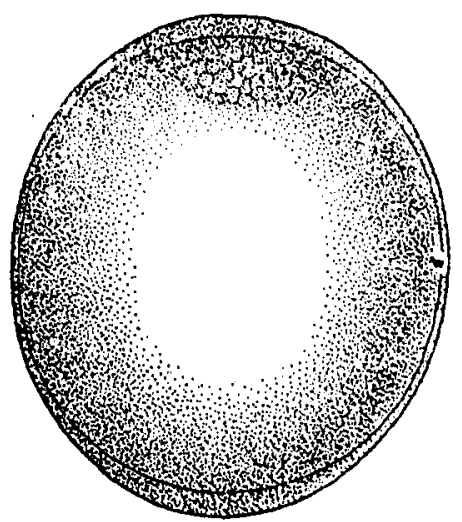

34

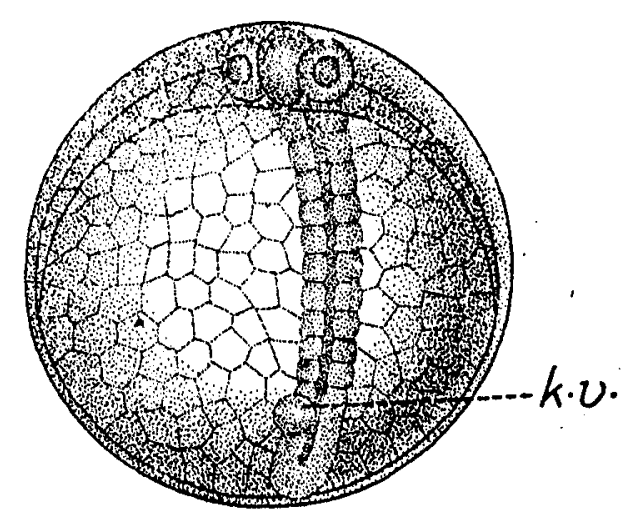

35 FIg. 34. Egg from the spawn mass, $\times 70$. FIG. 35. Egg from the spawn mass,
Second day, $\times 70$.

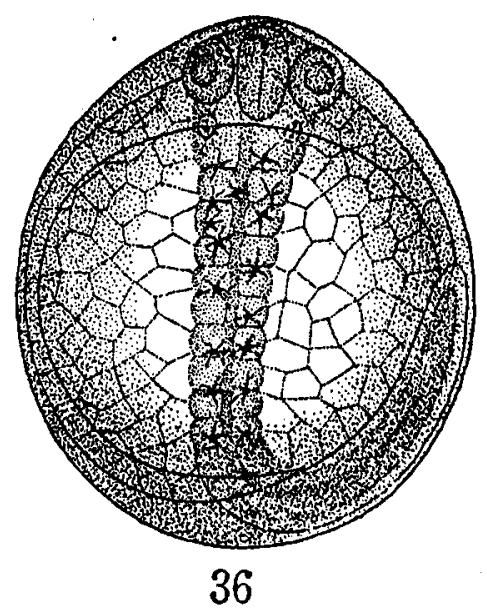

Fig. 36. Egg from the spawn mass, Third day, $\times 70^{\circ}$

Very little space is present all round the yolk mass and owing to the growth of the embryo a fairly wide space has formed at the anterior region of the
egg.

Third Day.-The embryo has grown longer and occupies nearly threefourths the circumference of the yolk mass (Fig. 36). The auditory vesicles have formed. The heart has begun to beat very faintly. No movement of the embryo is seen in this stage. Anteriorly the egg membrane gets stretched consequent on the growth of the embryo.

Black stellate chromatophores have appeared on the ventral side of the anterior region of the embryo.

Newly Hatched Larva.-On the fourth day most of the larvæ had hatched out from the eggs but were inside the capsules where they performed lashing movements with their tails, there being hardly sufficient space for 
Studies on some Fish Eggs and Larva of the Madras Plankton 203

the larvæ to move about. The newly hatched larvæ measure $1.2 \mathrm{~mm}$. in length and the yolk mass is fairly large and oval in shape (Fig. 37). The myotomes are not sufficiently clear in the newly hatched larvæ for. the determination of their number.

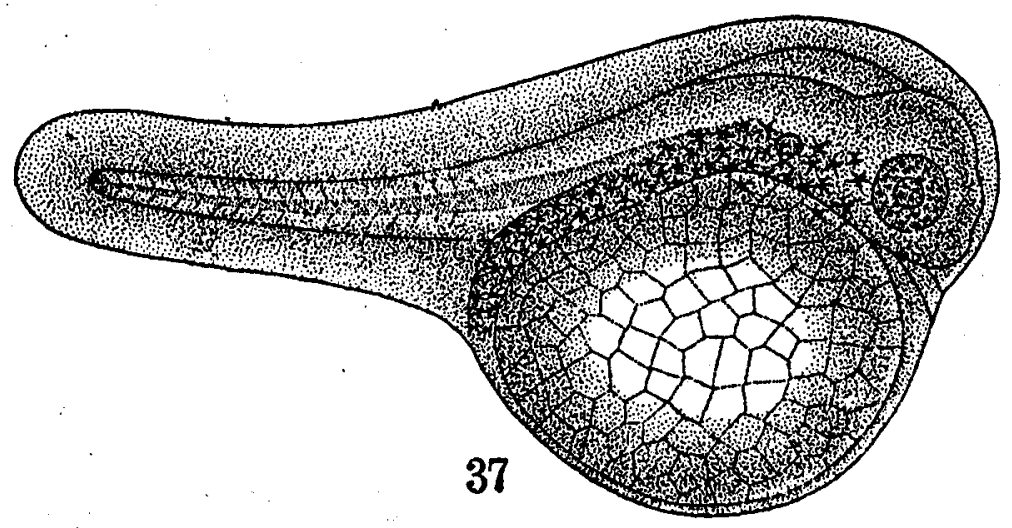

FIG. 37. Newly hatched larva, $\times 70$.

Pigmentation is restricted to the ventral side of the embryo, the dorsal side of the yolk mass and the posterior end of the alimentary tract. Numerous black stellate chromatophores are present in these regions and to the naked eye, this pigmented portion of the larva appears as a short black line in contrast with the other transparent portions. Similar chromatophores one or two in number may be present on the surface of the yolk mass. The eyes are also pigmented uniformly with many small black chromatophores having a few short branches. The larvæ in the capsules along the cut ends of the spawn mass had managed to escape from the jelly and were observed to float sideways on the surface of the water.

One-Day Old Larva.-Most of the one-day old larvæ had escaped from the jelly of the spawn mass owing to the disintegration of the latter. The liberated larvæ were quite active in their movements swimming vertically up and down the water in the aquarium. The larvæ measure now $1.35 \mathrm{~mm}$. in length. The yolk has diminished considerably in size (Fig. 38). Though the myotomes are not clear, about twenty-one of them could be made out with some difficulty with the anal opening below the seventh myotome. The muscle fibres of the myotomes have the crossed arrangement as in the clupeoid larvæ. Faint indications of the caudal fin rays have begun to appear in the one-day old larva.

The pigmentation present in the previous stage is somewhat intensified in this stage and no other region of the larvæ acquires pigment cells, 
Two-Day Old Larva.-In the two-day old larvæ no appreciable changes have taken place. The larvæ have elongated and measure now $1.45 \mathrm{~mm}$. in length. The yolk mass has further diminished in size (Fig. 39). The
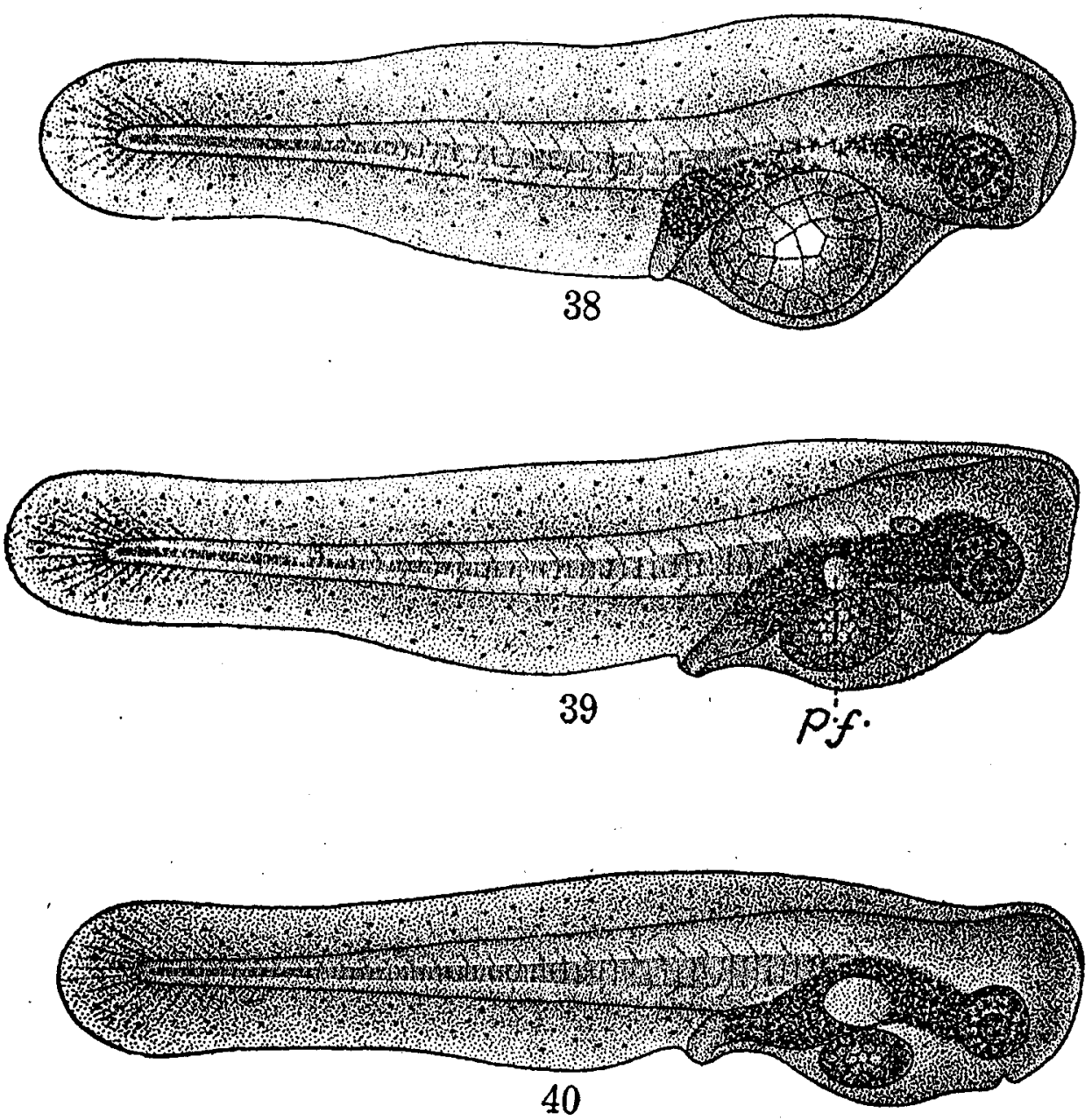

Fig. 38. One-day old larva, $\times$ 70. Frg. 39. Two-day old larva, $\times 70$. Fig. 40. Three-day old larva, $\times 70$.

segmented nature of the yolk is lost in this stage only and the yolk mass presents a granular appearance. The rudiment of the pectoral fin has formed as a bud-like prominence above the yolk mass. The caudal fin rays are prominent in this stage.

The original pigmentation remains unchanged but has become intense owing to the increased number and ramification of the stellate chromatophores. The larvæ now frequent the bottom of the aquarium where they
swim about actively. 
Three-Day Old Larva.-In the three-day old larva, there is no increase in length. The granular yolk has decreased still further (Fig. 40). The mouth has formed. The pectoral fins have increased in size. The caudal fin rays are very prominent. The pigmented region of the alimentary canal and the eyes of the larvæ appear jet black due to the intense accumulation of black stellate chromatophores. The larvæ were almost inactive in this stage resting at the bottom of the aquarium and thereby falling easy victims to the attacks of the numerous ciliates present in the sea water. Even though the greatest care was taken to keep the larva in a healthy living condition, most of them were in a dead or dying condition on the eighth day and, therefore, further development of the larvæ could not be studied.

Marine fishes in general liberate eggs which float independently on the surface of the sea. The extreme rarity of occurrence of spawn masses is shown by the fact that Ehrenbaum (1909) describes only the eggs of Lophius piscatorius as forming a mass in the large collection of fish eggs and larve examined by him from the plankton of the North Sea. In Lophius piscatorius each capsule encloses only a single egg having a single oil globule in the clear unsegmented yolk and as such the present spawn mass cannct be considered as coming under Pediculati. Taking into consideration the characters of the other eggs whose identity is known, only the eggs of carangoids, clupeoids and apodes are known to have segmented yolk, and in the other groups of fishes the segmentation of yolk is rare (Delsman, 1926). The apodan eggs are easily distinguishable by their characteristic features. The identification, therefore, rests between the clupeoid and the carangoid eggs and since the eggs show some features characteristic of both the families it is very difficult to determine the spawn mass more definitely. The nature of the segmentation of the yolk and the crossed arrangement of the muscle fibres of the larvæ are characters which greatly favour the inclusion of the eggs under the clupeoid group. On the other hand the general pigmentation, the small myotome number and the short nature of the alimentary tract are characters which point to the carangoid group, although the single oil globule characteristic of the carangoid group is absent here. There is also the possibility that the spawn mass may belong to an entirely different family whose eggs are still unknown to Science.

\section{General Remarks}

The periodicity of breeding of marine animals of the tropics has engaged the attention of scientists in recent years. Semper (1881) made the suggestion that in the tropics where the temperature variation is comparatively. 
negligible there is apparently no periodicity in the breeding of marine ani mals especially of the Invertebrates. Orton (1920) correlated breeding in marine animals with temperature and concluded that where temperature conditions do not vary much, marine animals breed continuously. Some authors consider that the reproductive activity is dependent on salinity conditions rather than temperature. Malpas (1929) has shown that Margaritifera vulgaris breeds only during two periods in a year coinciding with the two monsoons and suggests that the stimulation for the maximum spawning to the conclusion that many species of and Aiyar (1939) also have come monsoon. They found that the outbreas fishes breed actively during the the environment probably caused by the rains act as a definite changes in spawning even in species which are continuoust as a definite stimulus to this study that the breeding of marine continuous breeders. It is clear from the cold season immediately succeeding fishes this Coast is intense during September or October as shown the outbreak of the monson in and larvæ in enormous numbers during this time. However intensity of the fish eggs is reached only this time. However, the numerical December and January when intense on at the height of the cold season almost all the marine fishes of the reproductive activity is exhibited by during the other parts of the year indicating that the fishes are extremely rare spawn during the other seasons.

Based on this study, it is presumed that most of the marine fishes of the Madras Coast spawn at a definite time of the day, either late in the even- ' ing or early in the morning. Unlike in temperate countries, the embryonic in about a day's time. The larvæ hatch out in a very usually takes place and they float helplessly owing to the buoyancy of the oil globules and the yolk till their development is completed and they become dependent on the environmental food. Exceptions are, however, found in some eggs the embryonic development of which is very slow and takes about three to four days for the liberation of the larvæ. These eggs are provided with additional protection in the form of a network of ridges on the egg membrane which greatly enhances its strength. The larva are hatched out from these eggs in a very advanced stage enabling them to lead an independent existence.

Lastly a word may be said of the possible use of the observed occurrence of pelagic fish eggs for such fishery purposes as locating shoals of fishes and their brceding places. Generally fishes spawn during a definite time of the day and the pelagic nature and rapid development of the eggs of 
marine fishes in the tropics make it possible to use their occurrence as an indication of the presence of the adult fishes in the vicinity and also for detecting their important spawning grounds.

\section{ACKNOWLEDGEMENTS}

This investigation was carried out during the years 1944-47 in connection with a scheme of research on the Fish Eggs and Larvæ of the Madras Plankton financed by the Imperial Council of Agricultural Research, New Delhi. I am grateful to Dr. N. Kesava Panikkar, the then Director of the University Zoological Research Laboratory, for his valuable help and criticisms. My thanks are also due to Prof. R. Gopala Aiyar for going through the typescript and making helpful suggestions.

\section{REFERENCES}

Delsman, H. C.

Ehrenbaum, E.

Hornell, J.

.. "Fish Eggs and Larvæ from the Java Sea. 5. Caranx kurra, macrosoma and crumenophthalmus," Treubia, 1926, 8, 199-211.

.. "Fish Eggs and Larvæ from the Java Sea. 12. The genus Engraulis," ibid., 1929, 11, 275-81.

.. "Fish Eggs and Larvæ from the Java Sea. 17. The genus Stolephorus," ibid., 1931, 13, 217-43.

.. "Fish Eggs and Larva from the Java Sea. 24. Myctophoidea," ibid., 1938, 16, 415-20.

.. “Eier und Larven von Fischen," Nordisches Plankton, 1909, 1, 1-413.

.. "The Flying-fish Fishery of the Coromandel Coast and the spawning habits of Cypsilurus," Madras Fish. Bull., 1923, 15, 99-108.

Job, T. J. and Jones, S. .. "Studies on the development of the Indian Garfish Tylosurus strongylurus (van Hass.) with notes on the young stages of Hemirhamphus gaimardi Cuv. \& Val.," Rec. Ind. Mus., 1938, 40, 245-53.

John, M. A.

.. "Pelagic Fish Eggs and Larvæ of the Madras Coast," Proc. 31st Indian Sci. Congr. (Abstract), 1944, 85-86.

Kuntz, A. *

.. "The embryology and larval development of Bairdiella chrysura and Anchovia mitchilli," Bull. Bur. Fish., 1913, 33, 3-19.

Malpas, A. H.

.. "IV. Age and Growth Rate of the Pearl Oyster," Cey. Journ. Sci., C. Fisheries, 1929, 3, 67-74.

Moses, S. T.

.. "A statistical accuunt of the fish supply of Madras," Madras Fish. Bull., 1923, 15, 131-66.

Nair, R. V.

.. "Fish Eggs and Larvæ of the Madras Plankton," Proc. 33rd Indian Sci. Congr. (Abstract), 1946, 127.

Nayudu, M. R.

.. "A note on the eggs and early embryonic development of Cypsilurus," Madras Fish. Bull., 1923, 15, 109-12.

Nishịawa, T, *

.. "On the development of Engraulis japonicus," Journ. Fish. Bur. Tokyo, 1901, 10. 
Orton, J. H.

Raffacle, $F$.

Panikkar, N. K. and Aiyar, R. G.

Semper, $K$.

Wenckebach, K. F. *
. "Sea-temparature, Breeding and Distribution in Marine Animals," Journ. Mar. Biol. Assoc., 1920, 12, 339-66.

.. "Le uova galleggianti e le larva dei Teleosti nel Golfo di Napoli," Mitt. Zool. Stat. Neapel., 1888, 8, 1-84. "Observations on breeding in brackish water animals of Madras," Proc. Indian Acad. Sci., 1939, 9, 343-64.

.. “Animal Life," Inter. Sci. Ser., 1881, London.

.. "Verslag omtrent op de ansjovis betrekking hebbende onderzoeingen", Verslag Staat Nederl. Zeevischerijen over 1886, 1887.

Note.-Only the important references are given here particularly those mentioned in the text and dealing with the eggs of tropical fishes. References marked with an asterisk have not been referred to in the original.

\section{KEY TO LETTERING}
k. v. $\quad$.. Kupffer's vesicle.
p.f. $\quad$.. pectoral fin.
j.g. $\quad$.. oil globule.
t. .. tentacle. 